\title{
Analisis Kemampuan Literasi Sains Peserta didik SMP di Kota Cirebon
}

\author{
Fanni Zulaiha* \& Dewi Kusuma \\ Program Studi Pendidikan Fisika, Universitas Nahdlatul Ulama Cirebon \\ *Email: fanni.zulaiha@gmail.com
}

Received: 25 Oktober 2021； Accepted: 26 November 2021； Published: 23 Desember 2021

DOI: http://dx.doi.org/10.29303/jpft.v7i2.3049

\begin{abstract}
Scientific literacy was chosen as the main goal of science education. As the main goal, scientific literacy in science education is a picture of success in science education carried out by each country. In Indonesia, policies have been taken to support this goal although it is not clearly explained. To find out the success of science learning in the city of Cirebon, the researchers felt the need to analyze the scientific literacy skills of students in the city of Cirebon before providing concrete solutions to the problems faced. This study aims to provide an overview of the scientific literacy skills of junior high school students in Cirebon City. The research design used is quantitative research that uses descriptive (descriptive-quantitative) methods, namely research whose descriptions use size, number or frequency. The study was conducted on 7th grade students at the Cirebon City State Junior High School. The sample used was purposive sampling. The sample selected was State Junior High School with A and B accreditation. The scientific literacy ability in this study was viewed from the aspect of competence, knowledge and context. Based on the results of data processing, as many as $72.13 \%$ of seventh grade junior high school students in the city of Cirebon have scientific literacy skills in a very low category. This scientific literacy becomes a reference in applying the ability and quality of science learning in Cirebon City.
\end{abstract}

Keywords: Scientific Literacy; Junior High School Student; Cirebon City

\section{PENDAHULUAN}

Penguasaan dasar-dasar sains dan matematika diyakini harus dimiliki oleh setiap individu yang hidup di abad ke-21 ini. Peserta Didik harus kenal dekat dengan konsep-konsep dasar sains, matematika, rekayasa, dan teknologi agar dapat berpikir kritis tentang dunia ini dan membuat keputusan cerdas dalam isu-isu pribadi dan kemasyarakatan (Muchlis, 2013). Penguasaan dasar-dasar sains dan matematika bisa didapatkan melalui pendidikan. Sehingga dapat dikatakan bahwa pendidikan merupakan elemen penting dalam membangun kehidupan di suatu negara. Karena pendidikan merupakan elemen yang penting, maka kualitas pendidikan harus baik. Literasi sains dipilih sebagai tujuan utama pendidikan sains. Literasi sains menurut OECD (2010) adalah kemampuan menggunakan pengetahuan ilmiah, mengidentifikasi pertanyaan dan menggambarkan bukti-bukti yang berdasarkan kesimpulan untuk dapat memahami dan membantu pembuatan kesimpulan tentang alam serta perubahan terhadap alam tersebut akibat aktivitas manusia. Literasi sains dianggap bisa digunakan untuk mempersiapkan generasi saat ini untuk menghadapi saat nanti. Hal ini selaras dengan hasil penelitian Holbrook \& Rannikmae, Sudarisman, dan Hayat (dalam Setiawan, Utari, dan Nugraha, 2017). Sebagai tujuan utama, literasi sains dalam pendidikan sains menjadi gambaran keberhasilan dalam pendidikan sains yang dilakukan oleh setiap Negara. Di Indonesia, sudah diambil kebijakan untuk mendukung tujuan ini walaupun tidak dijelaskan secara gamblang (Kemendikbud, 2018).

Hasil penilaian PISA terhadap Indonesia terkait dengan literasi sains menyebutkan bahwa sebagian besar Peserta Didik Republik Indonesia berada dalam 
level 1 literasi saintifik sedangkan sebagian kecil peserta didik Indonesia berada dalam level 2 literasi saintifik. Dua level ini terbilang rendah karena terdapat 6 level dalam penilaian PISA (Programme for International Student Assessment) (Setiawan, Utari, dan Nugraha, 2017). PISA merupakan studi literasi yang dilaksanakan oleh Organization for Economic Cooperation and Development (OECD) dan UNESCO Institute for Statistics. Program ini bertujuan untuk menganalisis secara berkala pada tingkat Internasional kemampuan literasi Peserta Didik. Hasil PISA 2018 menemukan bahwa Peserta Didik Indonesia bagus di dalam pemahaman untuk single text tetapi lemah dalam memahami multiple text. Hasil studi PISA 2018 yang dirilis oleh OECD juga menunjukkan bahwa kemampuan peserta didik Indonesia dalam membaca, meraih skor rata-rata yakni 371, dengan rata-rata skor OECD yakni 487. Kemudian untuk skor rata-rata matematika mencapai 379 dengan skor rata-rata OECD 487. Selanjutnya untuk sains, skor rata-rata peserta didik Indonesia mencapai 389 dengan skor rata-rata OECD yakni 489. Dari data tersebut terlihat bahwa Literasi Sains Peserta Didik Indonesia masih rendah. Temuan lainnya adalah bahwa Indonesia berada pada kuadran low performance dengan high equity (Erdani, Hakim, Lia, 2020; Hapsari, et al., 2020). Kemudian, ditemukan juga bahwa gender gap in performance ketimpangan performa belajar antara perempuan dan laki-laki tidak besar. Peserta didik perempuan lebih baik dari peserta didik laki-laki dalam semua bidang di PISA (Kemdikbud, 2019).

Melihat pentingnya kemampuan literasi sains, maka peneliti merasa perlu untuk menganalisis kemampuan literasi sains peserta didik SMP di Kota Cirebon. Peserta didik SMP Kota Cirebon merupakan kelompok sosial kecil yang merupakan masa depan dari pembangunan suatu kota dan Negara. Oleh karena itu, Peneliti merasa perlu untuk mengetahui kemampuan literasi sains peserta didik di Kota Cirebon sebelum memberikan solusi konkret atas permasalahan yang dihadapi.

Literasi sains menurut PISA 2015 adalah kemampuan untuk terlibat dengan isu-isu ilmiah yang terkait dan dengan ideide ilmiah sebagai warga yang reflektif (OECD, 2019). Literasi sains juga didefinisikan oleh AAAS (American Association for the Advancement of Science) dengan Project 2061 sebagai kapasitas untuk menggunakan pengetahuan ilmiah, mengidentifikasi pertanyaanpertanyaan dan untuk menarik kesimpulan berdasarkan bukti-bukti agar dapat memahami dan membantu membuat keputusan tentang dunia alami dan interaksi manusia dengan alam. Sedangkan menurut Gbamanja (dalam Adolphus dan Arokoyu, 2012) mendefinisikan literasi sains sebagai pengetahuan dan pemahaman tentang peristiwa dan kejadian di lingkungan.

Berdasarkan framework PISA 2018 aspek literasi sains terdiri dari aspek konteks, pengetahuan, kompetensi, dan sikap yang dijelaskan secara rinci pada Tabel 1.

Tabel 1. Tujuan Penilaian PISA 2018

\begin{tabular}{|c|c|}
\hline Konteks & $\begin{array}{l}\text { Pribadi/ individu, nasional, Lokal } \\
\text { dan isu global, pada saat ini atau } \\
\text { yang lalu, yang memerlukan } \\
\text { pemahaman sains dan teknologi }\end{array}$ \\
\hline Pengetahuan & $\begin{array}{l}\text { Pemahaman tentang fakta-fakta } \\
\text { utama, dan teori-teori penjelasan } \\
\text { yang membentuk dasan } \\
\text { pengetahuan ilmiah. Pengetahuan } \\
\text { tersebut meliputi pengetahuan } \\
\text { tentang alam dan teknologi artefak } \\
\text { (konten pengetahuan), } \\
\text { pengetahuan tentang bagaimana } \\
\text { ide-ide tersebut diproduksi } \\
\text { (pengetahuan prosedural) dan } \\
\text { pemahaman tentang alas an yang } \\
\text { mendasari untuk prosedur ini dan }\end{array}$ \\
\hline
\end{tabular}


pembenaran yang mereka gunakan (pengetahaun epistemic)

Kemampuan untuk menjelaskan fenomena ilmiah, mengevaluasi

Kompetensi dan merancang penyelidikan ilmiah, menginterprestasikan data dan bukti ilmiah.

Sikap peserta didik terhadap ilmu pengetahuan ditunjukan dengan minat dalam sains dan teknologi,

Sikap menilai pendekatan ilmiah melalui penyelidikan, persepsi dan kesadaran akan masalah lingkungan

Sumber: OECD (2019)

\section{METODE PENELITIAN}

Desain penelitian yang digunakan adalah penelitian kuantitatif yang menggunakan metode deskriptif (deskriptifkuantitatif) yaitu penelitian yang gambarannya menggunakan ukuran, jumlah atau frekuensi. Pengumpulan dan pengolahan data penelitian dilakukan dengan menyajikan data apa adanya. Penelitian yang dilakukan tidak memberikan perlakuan, manipulasi atau pengubahan pada variabel-variabel bebas, tetapi menggambarkan suatu kondisi apa adanya (Sukmadinata, 2012). Penelitian ini bertujuan untuk memberikan gambaran profil capaian literasi sains peserta didik SMP di kota Cirebon yang ditinjau dari tiga aspek listerasi sains, yakni konten, proses, dan konteks. Penelitian dilakukan pada peserta didik kelas VII di SMP Negeri Kota Cirebon. Sampel yang digunakan menggunakan purposive sampling. Sampel yang dipilih yaitu Sekolah Menengah Pertama Negeri dengan Akreditasi A dan B.

Instrumen literasi sains yang digunakan mengadopsi instrumen Literasi Sains OECD PISA assessment tahun 2018. Butir-butir asesmen literasi sains tahun 2018 merupakan subset dari butir asesmen literasi sains tahun 2015; sebagian besar item ini dibuat pada tahun 2015 untuk mencerminkan kerangka kerja sains PISA
2015 yang diperbarui dan karenanya berbeda dari item yang digunakan dalam penilaian sebelum tahun 2015 (OECD, 2019). Kompetensi literasi sains yang diukur pada PISA 2018 seperti yang dijelaskan pada Tabel 1. Instrumen yang digunakan berupa soal tes berbentuk pilihan ganda dan esay. Soal tes disajikan secara online menggunakan google form.

Analisis data yang dilakukan pada penelitian ini terdiri dari beberapa tahap, yaitu:

a. Memberikan skor pada jawaban peserta didik sesuai dengan skor yang ditetapkan PISA yaitu jawaban benar diberi skor 2 dan jawaban salah diberi skor 0 . Khusus pertanyaan uraian jika jawaban kurang lengkap atau sebagian mendapat skor 1 .

b. Melakukan perhitungan persentase hasil capaian literasi sains peserta didik :

$$
\text { Persentase }(\mathrm{P})=\frac{J_{b}}{N} \times 100 \%
$$

$J_{b}$ : Jumlah pertanyaan yang dijawab benar

$N$ : Jumlah skor maksimal

c. Setelah dipersentasekan data dideskripsikan secara umum berdasarkan kompetensi, konteks, dan pengetahuan literasi sains dengan kategori di Tabel 2.

Tabel 2. Kriteria Interpretasi Skor

\begin{tabular}{cl}
\hline Interval Kriteria & \multicolumn{1}{c}{ Kriteria } \\
\hline $86 \% \leq \mathrm{P}<100 \%$ & Sangat Baik \\
$72 \% \leq \mathrm{P}<85 \%$ & Baik \\
$58 \% \leq \mathrm{P}<71 \%$ & Cukup \\
$43 \% \leq \mathrm{P}<57 \%$ & Rendah \\
$\mathrm{P} \leq 43 \%$ & Sangat Rendah \\
\hline
\end{tabular}

Sumber: Djaali dan Muljono (2008).

\section{HASIL DAN PEMBAHASAN Hasil}

Instrumen literasi sains yang digunakan dalam penelitian ini mengadopsi instrumen literasi sains OECD PISA tahun 2018. Instrumen literasi sains yang digunakan OECD menggunakan bahasa Inggris, sehingga Peneliti melakukan 
penerjemahan soal-soal literasi ke dalam bahasa Indonesia. Untuk menguji validitas soal literasi sains versi bahasa Indonesia dilakukan uji kesahihan terjemahan oleh ahli bahasa (Rahman, 2020). Prosedur yang dilakukan untuk validasi bahasa yaitu soal literasi versi bahasa Inggris diterjemahkan terlebih dahulu oleh Peneliti ke dalam bahasa Indonesia. Setelah itu, Peneliti menggunakan format yang sudah disediakan meminta Validator I untuk menerjemahkan ke dalam bahasa Inggris. Hasil terjemahan dari Validator I diserahkan ke Validator II untuk diterjemahkan kembali ke bahasa Indonesia. Dokumen inilah yang kemudian digunakan oleh Peneliti sebagai instrumen penelitian yang sudah divalidasi oleh ahli.

Penelitian ini dilakukan pada peserta didik kelas VII di SMP Negeri Kota Cirebon. Jumlah sampel yang digunakan dalam penelitian ini adalah 61 peserta didik dari sekolah dengan akreditasi A dan akreditasi B di Kota Cirebon. Soal literasi sains dibuat dalam bentuk online untuk memudahkan peserta didik dalam mengerjakan soal di masa Pandemi Covid19 ini. Aspek penilaian yang diukur pada penelitian ini adalah aspek kompetensi, pengetahuan dan konteks (Andriani, Saparini, Akhsan, 2018).

Tabel 3, 4, 5 menunjukkan persebaran aspek-aspek literasi sains pada instrumen penelitian yang digunakan.

Tabel 3. Persebaran aspek kompetensi literasi sains pada instrumen penelitian

\begin{tabular}{lc}
\hline \multicolumn{1}{c}{ Kompetensi Literasi Sains } & $\begin{array}{c}\text { Jumlah } \\
\text { Soal }\end{array}$ \\
\hline Menjelaskan Fenomena Ilmiah & 5 \\
\hline $\begin{array}{l}\text { Mengevaluasi dan mendesain } \\
\text { penelitian ilmiah }\end{array}$ & 5 \\
\hline $\begin{array}{l}\text { Menginterpretasikan data dan } \\
\text { bukti ilmiah }\end{array}$ & 6 \\
\hline
\end{tabular}

Tabel 4. Persebaran aspek pengetahuan literasi sains pada instrumen penelitian

\begin{tabular}{lc}
\hline \multicolumn{1}{c}{ Pengetahuan } & Jumlah Soal \\
\hline Konten & 8 \\
\hline Prosedural & 6 \\
\hline Epistemik & 2 \\
\hline
\end{tabular}

Tabel 5. Persebaran aspek konteks literasi sains pada instrumen penelitian

\begin{tabular}{lc}
\hline \multicolumn{1}{c}{ Pengetahuan } & $\begin{array}{c}\text { Jumlah } \\
\text { Soal }\end{array}$ \\
\hline Personal & 5 \\
\hline Lokal/ Nasional & 5 \\
\hline Global & 6 \\
\hline
\end{tabular}

Berdasarkan hasil pengolahan data didapatkan hasil sebagai berikut:

\section{a. Kompetensi Literasi Sains}

Berdasarkan hasil tes kemampuan Literasi Sains didapatkan hasil bahwa sebanyak 72,13\% siswa SMP di Kota Cirebon masih tergolong kategori sangat rendah. Persentase capaian hasil rata-rata yang didapat sebesar 36. Pada Gambar 1 disajikan hasil pengolahan data rata-rata skor tiap kompetensi literasi sains peserta didik kelas VII SMP di kota Cirebon.

Berdasarkan Gambar 1 diketahui bahwa capaian hasil rata-rata kemampuan literasi sains peserta didik kelas VII SMP di Kota Cirebon berdasarkan kompetensi literasi berada dalam kategori rendah dan sangat rendah. Adapun penjelasan persentase jumlah siswa tiap kategori komponen kompetensi literasi sains dijelaskan pada Gambar 2 sampai dengan Gambar 4.

Berdasarkan Gambar 2, diketahui bahwa sebanyak $69 \%$ peserta didik dalam kategori sangat rendah untuk kompetensi menjelaskan fenomena ilmiah. Hal ini menggambarkan bahwa sebanyak 69\% peserta didik tidak mampu mengingat dan menerapkan pengetahuan ilmiah yang sesuai, serta tidak dapat mengidentifikasi, menggunakan, dan menjelaskan suatu model dan representasi. 


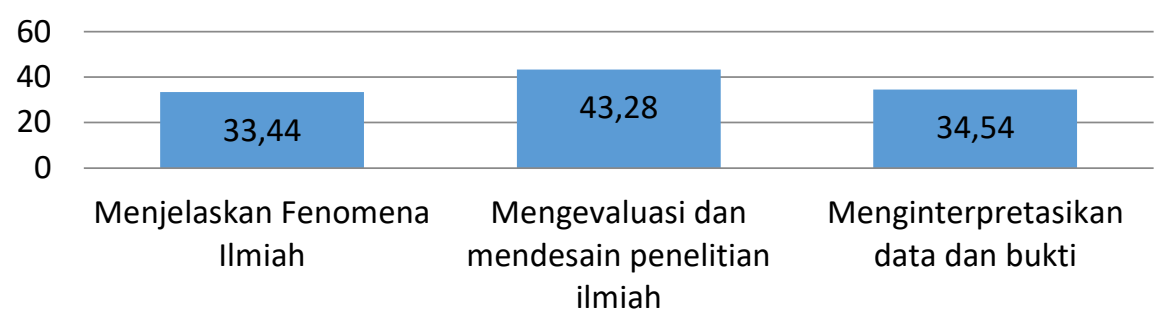

- Persentase Capaian Hasil Rata-Rata

Gambar 1. Persentase Capaian Hasil Rata-Rata Kompetensi Literasi Sains Peserta didik Kelas VII SMP di Kota Cirebon

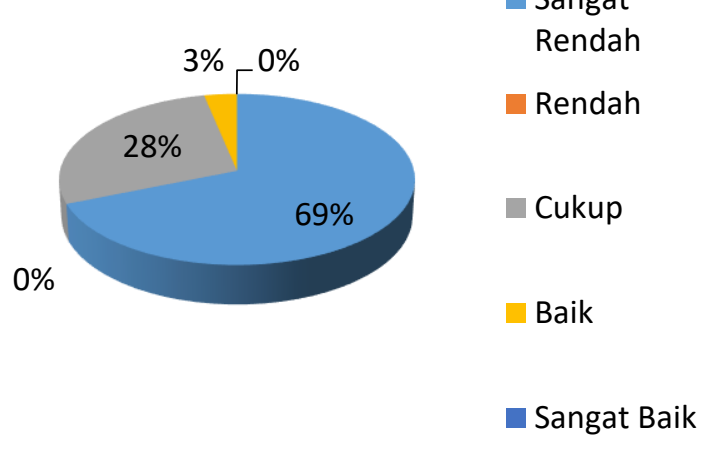

Gambar 2. Grafik Persentase Jumlah Peserta didik pada Kompetensi Menjelaskan Fenomena Ilmiah

Selain itu, kompetensi ini juga menggambarkan tentang kemampuan peserta didik dalam membuat dan membenarkan prediksi yang tepat, menawarkan hipotesis yang jelas, dan menjelaskan implikasi potensi pengetahuan ilmiah bagi masyarakat. Dengan kategori ini, artinya Peserta didik tidak memiliki kemampuan-kemampuan tersebut.

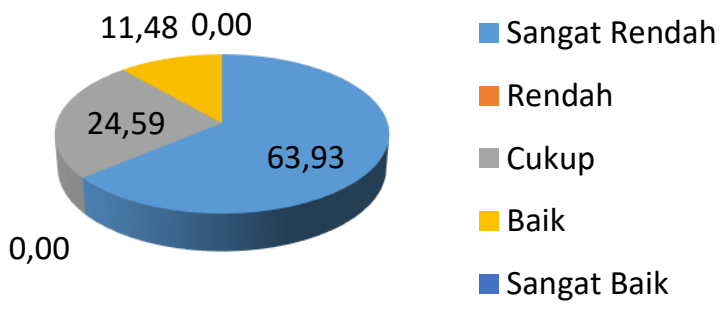

Gambar 3. Grafik Persentase Jumlah Peserta didik pada Kompetensi Mengevaluasi dan Mendesain Penelitian Ilmiah
Berdasarkan Gambar 3, diketahui bahwa $63,93 \%$ peserta didik dengan kategori sangat rendah pada kompetensi mengevaluasi dan mendesain penelitian ilmiah. Artinya sebanyak $63,93 \%$ peserta didik belum memiliki kemampuan untuk mengidentifikasi pertanyaan dalam sebuah penelitian ilmiah. Selain itu, peserta didik juga belum memiliki kemanpuan untuk membedakan pertanyaan untuk menyelidiki secara ilmiah. Pada kompetensi ini, terdapat $11,48 \%$ peserta didik berada dalam kategori baik, yang artinya peserta didik sudah mampu mengusulkan dan mengevaluasi cara mengeksplorasi pertanyaan yang diberikan secara ilmiah. Selain itu, peserta didik juga sudah mampu menjelaskan dan mengevaluasi berbagai cara yang ilmuwan gunakan untuk memastikan kebenaran data dan objektivitas.

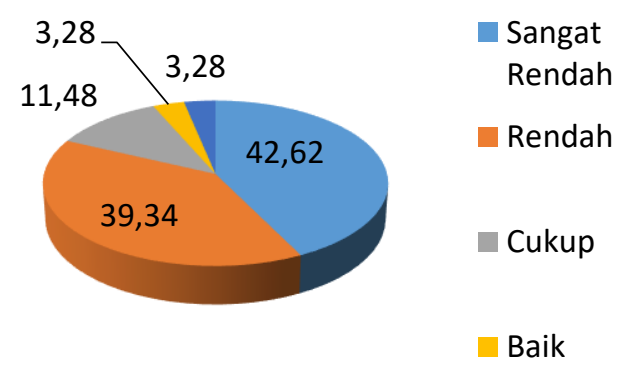

Gambar 4. Grafik Persentase Kategori Kompetensi Menginterpretasikan Data dan Bukti Peserta didik kelas VII SMPN di Kota Cirebon 
Berdasarkan Gambar 4, diketahui bahwa sebanyak $42,62 \%$ peserta didik masih dalam kategori sangat rendah untuk kompetensi menginterpretasikan data dan bukti. Hal ini menggambarkan bahwa peserta didik belum mampu mengubah data dari satu represntasi yang lain. Selain itu peserta didik belum mempunyai kemampuan untuk menganalisis dan menginterpretasikan data dan menarik kesimpulan yang tepat. Peserta didik juga belum mampu mengidentifikasi asumsi, bukti, dan penalaran dalam ilmu pengetahuan. Dari Gambar 4 tersebut, terdapat 3,28\% peserta didik dari sampel tersebut yang berkategori sangat baik. Artinya kelompok peserta didik tersebut telah mampu membedakan argumen yang didasarkan pada bukti ilmiah/ teori dan pertimbangan-pertimbangan lain. Selain itu juga peserta didik tersebut telah mampu mengevaluasi argumen ilmiah dan bukti dari sumber yang berbeda (misalnya koran, internet, dan jurnal).

Target distribusi skor kompetensi saintifik tiap kompetensi berdasarkan PISA 2018 Assessment and Analytical Framework dan hasil capaian persentase skor poin disajikan pada Tabel 6 .

Tabel 6. Distribusi skor kompetensi saintifik

\begin{tabular}{lcc}
\hline Kompetensi Saintifik & $\begin{array}{c}\text { Target } \\
\text { \% Skor } \\
\text { Poin }\end{array}$ & $\begin{array}{c}\text { Capaian } \\
\text { \% Skor } \\
\text { Poin }\end{array}$ \\
\hline $\begin{array}{l}\text { Menjelaskan Fenomena } \\
\text { Ilmiah }\end{array}$ & $40-50 \%$ & $17,4 \%$ \\
$\begin{array}{l}\text { Mengevaluasi dan } \\
\text { mendesain penelitian }\end{array}$ & $20-30 \%$ & $13,5 \%$ \\
$\begin{array}{l}\text { ilmiah } \\
\text { Menginterpretasikan data } \\
\text { dan bukti ilmiah }\end{array}$ & $30-40 \%$ & $24,5 \%$ \\
\hline Total & $100 \%$ \\
\hline
\end{tabular}

(Sumber: OECD, 2019)

Berdasarkan Tabel 6 diketahui bahwa kompetensi literasi sains peserta didik kelas VII SMPN di kota Cirebon masih dibawah target skor yang ditetapkan oleh OECD.

\section{b. Aspek Pengetahuan}

Pada Gambar 5 disajikan hasil pengolahan data aspek pengetahuan literasi sains peserta didik kelas VII SMP di kota Cirebon

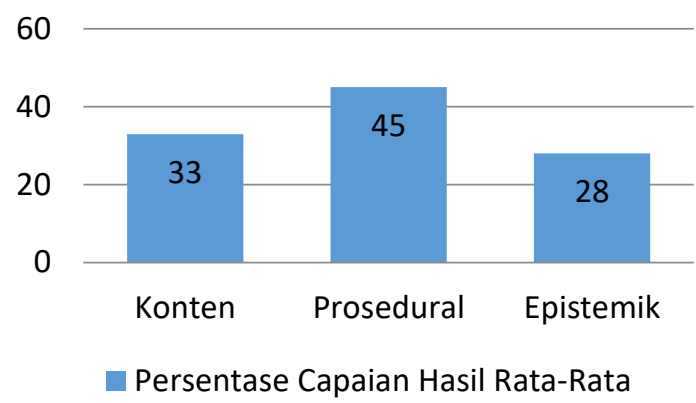

Gambar 5. Persentase Capaian Hasil Rata-rata Aspek Pengetahuan Literasi Sains

Berdasarkan Gambar 5 diketahui bahwa capaian hasil rata-rata aspek pengetahuan literasi sains peserta didik kelas VII SMP di Kota Cirebon berada dalam kategori rendah dan sangat rendah. Adapun penjelasan tiap pengetahuan literasi sains dijelaskan pada Gambar 6 sampai dengan Gambar 8.

Pengetahuan konten tidak hanya merujuk pada konsep-konsep semata, tetapi konsep kunci yang diperlukn untuk memahami fenomena alam dan perubahan yang dilakukan terhadap alam melalui aktivitas manusia. (Nofiana, \& Julianto, 2018). OECD (2019) menentukan kriteria pemilihan konten sains sebagai berikut:

- Relevan dengan situasi kehidupan nyata;

- Mewakili konsep ilmiah penting atau teori penjelas utama yang memiliki kegunaan berjangka panjang.

Berdasarkan hasil pengolahan data pengetahuan konten sains didapatkan data seperti pada Gambar 6 .

Pada Gambar 6 terlihat bahwa 57\% peserta didik masih dalam kategori sangat rendah skor pengetahuan kontennya, dan $8 \%$ peserta didik termasuk ke dalam kategori baik untuk pengetahuan konten. 


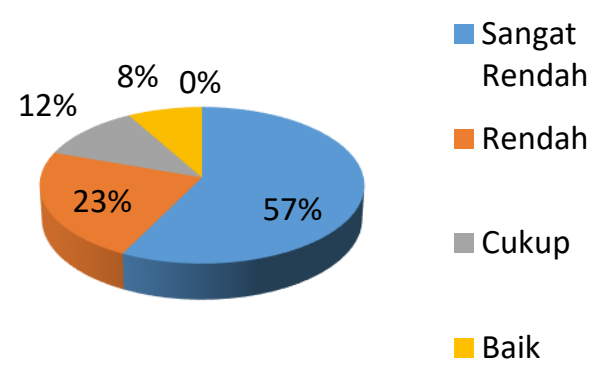

Gambar 6. Grafik Persentase Jumlah Peserta Didik pada Pengetahuan Konten

Adapun hasil pengolahan data untuk pengetahuan prosedural disajikan pada Gambar 7.

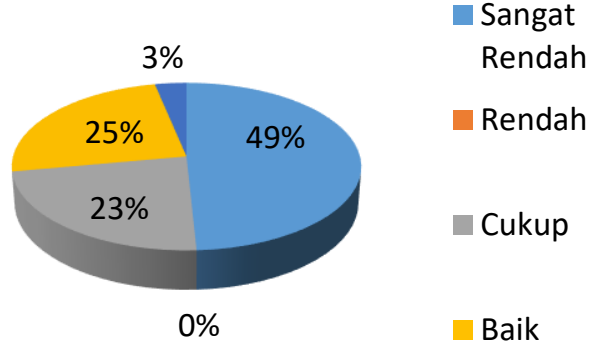

Gambar 7. Grafik Persentase Jumlah Peserta Didik pada Pengetahuan Prosedural

Tujuan fundamental sains adalah menghasilkan penjelasan tentang dunia material. Penjelasan tentatif pertama kali dikembangkan dan kemudian diuji melalui penyelidikan empiris. Penyelidikan empiris bergantung pada konsep dan metode tertentu yang mapan seperti gagasan variabel dependen dan independen, pengendalian variabel, berbagai jenis pengukuran dan bentuk kesalahan, metode untuk meminimalkan kesalahan, pengenalan pola umum yang diamati dalam data, dan metode penyajian data. Pengetahuan tentang konsep dan prosedur standar yang penting untuk penyelidikan ilmiah inilah yang mendasari pengumpulan, analisis, dan interpretasi data ilmiah. Ide-ide seperti itu membentuk tubuh pengetahuan prosedural, yang juga disebut konsep bukti (Roberts \& Glaesser, 2010).
Pengetahuan semacam itu dibutuhkan baik untuk melakukan penyelidikan ilmiah maupun terlibat dalam tinjauan kritis terhadap bukti yang mungkin digunakan untuk mendukung klaim tertentu. Berdasarkan Gambar 7, diketahui bahwa 49\% peserta didik SMPN di Kota Cirebon masih termasuk ke dalam kategori sangat rendah.

Pengetahuan epistemik adalah pengetahuan tentang konstruksi dan fitur yang menentukan penting untuk proses pembangunan pengetahuan dalam sains (misalnya hipotesis, teori dan observasi) dan peran mereka dalam membenarkan pengetahuan yang dihasilkan oleh sains (Duschl, 2008). Peserta didik menggunakan pengetahuan epistemik untuk menjelaskan, dengan contoh, perbedaan antara teori ilmiah dan hipotesis atau antara fakta ilmiah dan observasi. Pengetahuan epistemik mencakup pemahaman bahwa konstruksi model, baik itu representasi langsung, abstrak atau matematis, adalah ciri utama sains dan bahwa model semacam itu lebih mirip dengan peta daripada gambar akurat dari dunia material. Peserta didik juga harus menyadari bahwa kata "teori" tidak digunakan dengan cara yang sama dalam sains seperti dalam bahasa sehari-hari, di mana ia merupakan sinonim untuk "menebak" atau "dugaan". Sedangkan pengetahuan prosedural diperlukan untuk menjelaskan apa yang dimaksud dengan strategi pengendalian variabel, pengetahuan epistemik diperlukan untuk menjelaskan mengapa penggunaan strategi pengendalian variabel sangat penting dalam membangun pengetahuan ilmiah. Individu yang melek ilmiah juga akan memahami bahwa para ilmuwan menggunakan data untuk memajukan klaim atas pengetahuan dan argumen itu adalah ciri umum sains.

Para peserta didik ini juga memahami peran dan pentingnya tinjauan sejawat 
sebagai mekanisme yang telah ditetapkan komunitas ilmiah untuk menguji klaim baru. Pengetahuan epistemik dengan demikian memberikan dasar pemikiran untuk prosedur dan praktik di mana para ilmuwan terlibat dan dasar untuk dasar kepercayaan pada klaim yang dibuat sains tentang dunia alami. Berdasarkan hasil pengeolahan data didapatkan hasil seperti yang tersaji pada Gambar 8.

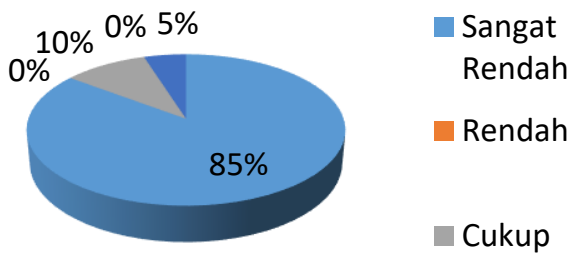

Gambar 8. Grafik Persentase Jumlah Peserta Didik pada Pengetahuan Epistemik

Target distribusi skor kompetensi saintifik tiap kompetensi berdasarkan PISA 2018 Assessment and Analytical Framework (OECD, 2019) disajikan pada Tabel 7.

Tabel 7. Target distribusi skor jenis pengetahuan

\begin{tabular}{lrr}
\hline Pengetahuan & $\begin{array}{c}\text { Target } \\
\text { \% Skor Poin }\end{array}$ & $\begin{array}{c}\text { Capaian } \\
\text { \% Skor } \\
\text { Poin }\end{array}$ \\
\hline Konten & $54-66 \%$ & $28 \%$ \\
Prosedural & $19-31 \%$ & $22 \%$ \\
Epistemik & $10-22 \%$ & $0,84 \%$ \\
\hline Total & $100 \%$ & \\
\hline
\end{tabular}

Berdasarkan Tabel 7 diketahui bahwa pengetahuan konten sains dan epistemik peserta didik kelas VII SMPN di kota Cirebon masih dibawah target skor yang ditetapkan oleh OECD. Adapun pengetahuan prosedural sudah sesuai target $\%$ skor poin.

\section{c. Aspek Konteks}

PISA 2018 menilai pengetahuan ilmiah menggunakan konteks yang mengangkat isu-isu terkait yang sering relevan dengan kurikulum pendidikan sains negara-negara peserta. Namun, item penilaian tidak terbatas pada konteks sains sekolah. Butir-butir dalam penilaian sains PISA 2018 dapat berhubungan dengan diri sendiri, keluarga, dan kelompok sebaya (personal), dengan masyarakat (lokal dan nasional) atau dengan kehidupan di seluruh dunia (global). Konteksnya mungkin melibatkan teknologi atau, dalam beberapa kasus, elemen sejarah yang dapat digunakan untuk menilai pemahaman peserta didik tentang proses dan praktik yang terlibat dalam memajukan pengetahuan ilmiah (OECD, 2019).

Konteks butir-butir dalam penilaian IPA PISA juga telah dikategorikan ke dalam lima aplikasi IPTEK. Namun, penilaian sains PISA bukanlah penilaian konteks. Sebaliknya, itu menilai kompetensi dan pengetahuan dalam konteks tertentu. Konteks-konteks ini dipilih karena relevansinya dengan minat dan kehidupan peserta didik dan karena mereka adalah area di mana literasi sains memiliki nilai khusus dalam meningkatkan dan mempertahankan kualitas hidup dan dalam pengembangan kebijakan publik. Pada Gambar 8 disajikan data hasil pengolahan data konteks literasi sains.

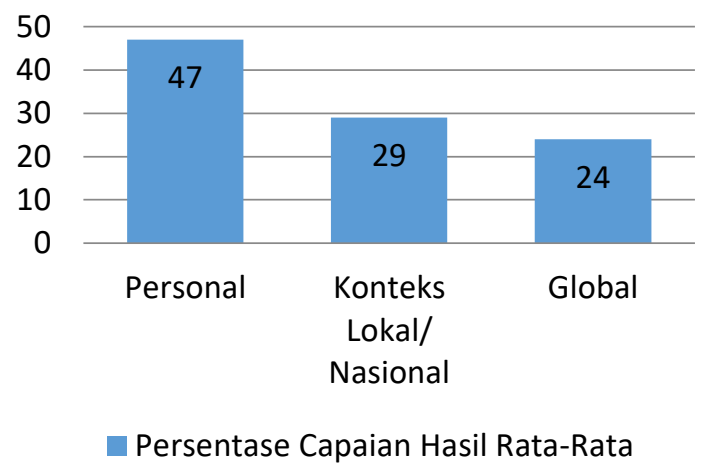

Gambar 8. Persentase Capaian Hasil Rata-Rata Aspek Konteks Literasi Sains

\section{Pembahasan}

Hasil pengolahan data menunjukkan bahwa kemampuan literasi sains peserta didik kelas VII di Kota Cirebon masih tergolong 
sangat rendah. Hal ini disebabkan pembelajaran IPA masih berfokus pada aspek hafalan, hal ini sesuai dengan temuan penelitian yang dilakukan oleh Nofiana \& Julianto (2017) dan Hasasiyah, et al. (2020). Menurut Nofiana dan Julianto (2017), adanya tuntutan terselesaikannya materi bahan ajar oleh guru sesuai target kurikulum memaksa siswa harus menerima konsep-konsep IPA yang mungkin belum sepenuhnya dipahami sehingga menimbulkan miskonsepsi atau hanya sekedar dihafalkan saja yang pada akhirnya akan terlupa. Rendahnya kemampuan literasi sains pada peserta didik di Kota Cirebon juga disebabkan karena rendahnya kemampuan peserta didik dalam memahami beberapa istilah dalam kegiatan penyelidikan ilmiah, dikarenakan peserta didik jarang melakukan kegiatan praktikum terlebih di saat Pandemi Covid-19 ini (Safitri \& Mayasari, 2018). Selain itu peserta didik tidak terbiasa mengerjakan soal dalam bentuk soal cerita panjang dan lemahnya kemampuan peserta didik untuk mengungkapkan isi wacana yang diberikan dan menafsirkan data dalam bentuk gambar, tabel, diagram dan bentuk penyajian lainnya (Andriani, Saparini, Akhsan, 2018; Ning, Roshayanti, Siswanto, 2020; Sujudi, et al., 2020, Hasasiyah, et al., 2020). Upaya yang bisa dilakukan untuk dapat meningkatkan kemampuan literasi sains diantaranya Guru harus mematangkan konsep literasi sains, memberikan pemahaman tentang literasi sains dan penerapan literasi sain dalam proses pembelajaran, contohnya dengan menggunakan berbagai jenis model pembelajaran yang bersifat student centered dan kegiatan laboratorium, menggunakan perangkat evaluasi yang berbasis literasi sains (Wulandari, dan Sholihin, 2016; Andriani, Saparini, Akhsan, 2018; Sujudi, et al., 2020; Haerani, Setiadi, Rasmi, 2020; Hasasiyah, et al., 2020). Pematangan konsep literasi sains juga harus dimulai dari tingkat sekolah dasar, oleh karena itu dibutuhkan guru yang mempunyai kompetensi profesionalisme yang baik (Sujudi, et al., 2020).

Pada aspek kompetensi literasi sains, kompetensi mengevaluasi dan mendesain penelitian ilmiah lebih tinggi dibandingkan kompetensi lainnya, hal ini dikarenakan selama pembelajaran daring akibat adanya pandemi Covid-19, peserta didik belajar menggunakan LMS (Learning Management System) berupa tugas-tugas pengumpulan literatur dan melakukan kajian dan pengamatan sesuai dengan topik pembelajaran. Kegiatan semacam ini mampu melatihkan kompetensi mengevaluasi dan mendesain penyelidikan ilmiah. Hal ini sesuai dengan penelitian yang dilakukan oleh Haerani, Setiadi, dan Rasmi (2020). Kompetensi lainnya lebih rendah dikarenakan peserta didik belum mampu mengaplikasikan konsep pengetahuan yang dimilikinya dalam situasi yang diberikan untuk menjelaskan atau mendeskripsikan fenomena dan mendeskripsikan perubahan, mengidentifikasi deskripsi, eksplanasi, dan prediksi yang sesuai (Wulandari, dan Sholihin, 2016; Haerani, Setiadi, dan Rasmi, 2020). Kompetensi menjelaskan fenomena secara ilmiah dibutuhkan peserta didik untuk mengingat kembali konten pengetahuan yang tepat pada keadaan yang diberikan dan menggunakannya untuk menginterpretasi dan menyediakan penjelasan untuk fenomena yang dihadirkan. Adapun penyebab rekndahnya kompetensi interpretasi data dan membuktikan data secara ilmiah rendah dikarenakan peserta didik belum memiliki kemampuan dalam menafsirkan bukti ilmiah atau data yang diperoleh melalui kegiatan pengamatan yang dipergunakan untuk menarik kesimpulan dan memberikan alasan yang tepat mengapa alasan tersebut dapat diterima ataupun ditolak (Haerani, Setiadi, dan Rasmi, 2020). Berdasarkan hasil wawancara diketahui bahwa peserta didik selalu merasa takut salah dan takut tidak 
diapreasi ketika membuat suatu keputusan. Adanya pengalaman masa lalu yang membuat peserta didik takut untuk membuat keputusan ini menjadi salah satu penyebab rendahnya kompetensi ini.

Pada aspek pengetahuan literasi sains. Pengetahuan prosedural memperoleh persentase capaian hasil lebih tinggi dari yang lainnya, hal ini berarti peserta didik telah mampu untuk menghasilkan representasi ataupun model prosedur yang lebih mudah dengan menyertakan sedikit langkah-langkah (Sholahuddin, et al., 2016). Walaupun lebih tinggi dibandingkan aspek pengetahuan literasi sains lainnya, hasil pengolahan data menunjukkan rata-rata pengetahuan prosedural peserta didik termasuk ke dalam kategori sangat rendah. Peserta didik belum mampu menganalisis informasi yang kompleks dalam sebuah narasi yang panjang dengan berbagai jenis modus representasi. Ketiga pengetahuan literasi sains ini saling berhubungan, rendahnya pengetahuan prosedural dan konten berpengaruh terhadap capain pengetahuan epistemic peserta didik. Peserta didik kesulitan untuk menjustifikasi penjelasan secara ilmiah terhdap suatu fenomena (Sholahuddin, et al., 2016).

Berdasarkan hasil penelitian menunjukan kemampuan literasi sains peserta didik kelas VII di Kota Cirebon dalam aspek konteks sains masih sangat rendah. Hal ini dikarenakan pembelajaran IPA masih bersifat parsial. Guru hanya menjelaskan konsep IPA tanpa mengaitkannya dalam kehidupan seharihari (Nofiana dan Julianto, 2017). Konteks pribadi menunjukkan capaian hasil yang lebih tinggi dibandingkan konteks lainnya. Hasil yang sama didapatkan pada penelitian Putri (2021). Hal ini menunjukkan bahwa konteks lain kurang familiar menyulitkan siswa untuk menjawab (Sholahuddin, et al. 2016).

Rendahnya kemampuan literasi sains peserta didik kelas VII di kota Cirebon juga disebabkan tidak efektifnya pembelajaran IPA selama masa pandemi Covid-19. Hal ini didukung berdasarkan hasil wawancara dengan Guru Pengajar IPA dan Wakil Kepala Sekolah bidang kurikulum. Pembelajaran di masa pandemi Covid-19 kurang efektif, terlebih untuk pembelajaran IPA. Surat Edaran Wali Kota Cirebon No. 443/SE.59-PEM tanggal 2 Juli 2021 tentang Pemberlakuan Pembatasan Kegiatan Masyarakat (PPKM) Darurat, mengatur kegiatan belajar mengajar di sekolah untuk dilakukan secaar online/ daring. Beberapa upaya dilakukan agar pembelajaran IPA tetap berjalan maksimal seperti dilakukan pembelajaran menggunakan aplikasi zoom dan Learning Management System (LMS). Tetapi banyak siswa yang terkendala perangkat dan keterbatasan jaringan dan kuota internet (Manili, Subagia, \& Citrawathi 2021) dan rendahnya motivasi belajar siswa sehingga tidak adanya daya penggerak siswa untuk mengerjakan tugastugas yang diberikan oleh Guru (Rahmawati dan Wulan, 2020; Manili, Subagia, \& Citrawathi 2021). Rendahnya salah satu dimensi literasi sains akan berpengaruh terhadap dimensi literasi sains lainnya. Rendahnya pemahaman konsep siswa terhadap pengetahuan sains akan berdampak pada rendahnya aplikasi sains. Fakta di lapangan menunjukkan meskipun siswa sangat pandai menghafal namun juga kenyataanya kurang terampil dalam mengaplikasikan pengetahuan yang dimilikinya. (Nofiana \& Julianto, 2017). Kemampuan literasi perlu dilatihkan sejak dasar. Kemampuan ini tidak serta merta dapat meningkat di jenjang menengah, kemampuan ini harus dilatihkan sejak tingkat dasar.

\section{PENUTUP}

Kemampuan literasi sains pada penelitian ini dilihat dari aspek kompetensi, pengetahuan dan konteks. Berdasarkan hasil pengolahan data, sebanyak $72,13 \%$ siswa SMP kelas VII di kota cirebon memiliki kemampuan literasi sains dengan kategori sangat rendah. Literasi sains ini menjadi 
acuan dalam menerapkan kemampuan dan kualitas pembelajaran IPA di Kota Cirebon.

\section{UCAPAN TERIMAKASIH}

Penulis mengucapkan terima kasih kepada Direktorat Sumber Daya, Direktorat Jenderal Pendidikan Tinggi, Kementerian Pendidikan, Kebudayaan, Riset dan Teknologi sebagai pemberi dana untuk penelitian ini dalam program Penelitian Dosen Pemula Tahun Anggaran 2021.

\section{REFERENSI}

Andriani, N., Saparini., \& Akhsan, H. (2018). Kemampuan Literasi Sains Fisika Siswa SMP kelas VII di Sumatera Selatan menggunakan Kerangka PISA (Program for International Student Assesment). Berkala Ilmiah Pendidikan Fisika, 6(3), 278-291.

Djaali, \& Muljono, P. (2008). Pengukuran dalam Bidang Pendidikan. Jakarta: PT Grasindo.

Duschl, R. (2008). Science Education in Three-Part Harmony: Balancing Conceptual, Epistemic, and Social Learning Goals. Review of Research in Education, 32(1), 268-291.

Erdani, Y., Hakim, L., \& Lia, L. (2020). Pengaruh Model Pembelajaran Inkuiri Terbimbing Terhadap Kemampuan Literasi Sains Siswa di SMP Negeri 35 Palembang. Jurnal Pendidikan Fisika dan Teknologi, 6(1), 45-52. doi:http://dx.doi.org/10.29303/jpft.v $\underline{6 i 1.1549}$

Haerani, S, A, S., Setiadi, D., \& Rasmi, D, A, C. (2020). Pengaruh Model Inkuiri Bebas Terhadap Kemampuan Literasi Sains. Jurnal Pijar MIPA, 15(2), 140-144. DOI: 10.29303/jpm.v15i2.1682

Hapsari, H., Fitriyanto, S., Hermansyah, H., Yahya, F., \& Walidain, S. (2020). Multimedia Interaktif Konsep
Gravitasi Berorientasi Pada Literasi Sains. Jurnal Pendidikan Fisika dan Teknologi, 6(2), 228-237. doi:http://dx.doi.org/10.29303/jpft.v $\underline{6 i 2.2097}$

Hasasiyah, S. H., Hutomo, B. A., Subali, B., \& Marwoto, P. (2020). Analisis Kemampuan Literasi Sains Siswa SMP pada Materi Sirkulasi Darah. Jurnal Penelitian Pendidikan IPA, 6(1), 5-9. https://doi.org/10.29303/jppipa.v6i1. $\underline{193}$

KEMDIKBUD. (2018). Peraturan enteri Pendidikan dan Kebudayaan Nomor 35 Tahun 2018 tentang Kurikulum 2013 Sekolah Menengah Pertama/ Madrasah Tsanawiyah. Jakarta: Kemendikbud

KEMDIKBUD. (2019). Hasil PISA Indonesia 2016: Akses Makin Meluas Saatnya Tingkatkan Kualitas. Diakses dari: https://www.kemdikbud.go.id/main/ blog/2019/12/hasil-pisa-indonesia2018-akses-makin-meluas-saatnyatingkatkan-kualitas 2019

Manili, D., Subagia, I., \& Citrawathi, D. (2021). Analisis Pengelolaan Pembelajaran IPA pada Masa Pandemi Covid-19 di SMP Negeri 6 Singaraja. Jurnal Imiah Pendidikan dan Pembelajaran, 5(3). doi:http://dx.doi.org/10.23887/jipp.v 5i3.38137

Muchlis, A. (2013). Sekali lagi, gawat darurat pendidikan. Diakses dari: http://www.bincangedukasi.com/sek ali-lagi-gawat-darurat-pendidikan/

Ning, D, R., Roshayanti, F., \& Siswanto, J. (2020). Profil Literasi Sains dan Berfikir Kreatif Siswa SMP Negeri 11 Pekalongan. Jurnal Edukasi Matematika dan Sains, 8(2), 150156.

DOI: http://doi.org/10.25273/jems.v $\underline{8 \mathrm{i} 2.6905}$

Nofiana, M., \& Julianto, T. (2018). Upaya Peningkatan Literasi Sains Siswa 
Melalui Pembelajaran Berbasis Keunggulan Lokal. Biosfer: Jurnal Tadris Biologi, 9(1), 24-35. Doi: https://doi.org/10.24042/biosf.v9i1.2 $\underline{876}$

Nofiana, M. (2017). Profil Kemampuan Literasi Sains Siswa SMP di Kota Purwokerto Ditinjau dari Aspek Konten, Proses, dan Konteks Sains. JSSH (Jurnal Sains Sosial dan Humaniora), 1(2), 77-84. doi:http://dx.doi.org/10.30595/jssh.v $\underline{1 i 2.1682}$

OECD. (2010). Assessing framework key competencies in reading, mathematics, and science. OECD Publishing

OECD. (2019). PISA 2018 Science Framework. OECD Publishing.

OECD. (2019). PISA 2018 Assessment \& Analytical Framework. OECD Publishing.

OECD. (2019). PISA 2018 Result (Volume 1): What students know and can do. OECD Publishing.

Putri, M, D. (2021). Identifikasi Kemampuan Literasi Sains Siswa di SMP Negeri 2 Pematang Tiga Bengkulu Tengah. GRAVITASI: Jurnal Pendidikan Fisika Dan Sains, 4(01), $9 \quad$ - 17. https://doi.org/10.33059/gravitasi.jpf $\underline{\text { s.v4i01.3610 }}$

Rahman, D. H. (2020). The validation of school burnout inventory-Indonesian version. Jurnal Penelitian Ilmu Pendidikan, 13(2), 85-93. doi: https://doi.org/10.21831/jpipfip.v13i 2.32579.dst

Rahmawati, A., \& Wulan, D. (2020). Motivasi Belajar Peserta Didik Ditinjau Dari Model Pembelajaran DiSTAD. Jurnal Pendidikan Fisika dan Teknologi, 6(2), 314-319. doi:http://dx.doi.org/10.29303/jpft.v $6 \mathrm{i} 2.2137$

Roberts, R., R. Gott and J. Glaesser .2010. 'Students' approaches to open- ended science investigation: the importance of substantive and procedural understanding”, Research Papers in Education, Vol. 25/4, pp. 377-407.

Safitri, Y., \& Mayasari, T. (2018). Analisis tingkat kemampuan awal siswa SMP/MTs dalam berliterasi sains pada konsep IPA. Prosiding Seminar Nasional Quantum, 165-170.

Setiawan, A, R., Utari, S., \& Nugraha, M, G. (2017). Mengkonstruksi Rancangan Soal Domain Kompetensi Literasi Saintifik Siswa SMP Kelas VIII Pada Topik Gerak Lurus. Jurnal Wahana Pendidikan Fisika, 2(2): 44-48.

Sholahuddin, A., Sari, M, M., Amin, C., \& Muslim, M. (2016). Tingkat Literasi Sains Siswa SMP Kotamadya Banjarmasin. Prosiding Seminar Nasional Pendidikan IPA, 75-84. Diakses dari: http://jbse.ulm.ac.id/index.php/PMP IPA/article/view/27/41

Sujudi, M, S., Idris, T., Suryanti., \& Handayani, P, H. (2020). Profil Kemampuan Literasi Sains Siswa SMP Islam As-Shofa Kota Pekanbaru Berdasarkan PISA. Journal of Natural Science and Integration, 3(1), 58-69. DOI: http://dx.doi.org/10.24014/jnsi .v3i1.9023

Sukmadinata, N, S. (2012). Metode Penelitian Pendidikan. Bandung: Remaja Rosdakarya.

Surat Edaran Wali Kota Cirebon No. 443/SE.59-PEM tanggal 2 Juli 2021 tentang Pemberlakuan Pembatasan Kegiatan Masyarakat (PPKM) Darurat

Wulandari, N., \& Solihin. (2016). Analisis Kemampuan Literasi Sains Pada Aspek Pengetahuan Dan Kompetensi Sains Siswa Smp Pada Materi Kalor. EDUSAINS, $\quad 8(1), \quad$ 66-73. doi:https://doi.org/10.15408/es.v8i1. $\underline{1762}$ 